\title{
Dam breaking in Brumadinho: an experience report on the debates in the disaster process
}

\author{
Rompimento da barragem em Brumadinho: um relato de experiência \\ sobre os debates no processo de desastres
}

Giulia Balbi Rodrigues da Costa', Geórgia Rolemberg Lau', Camilla Ferreira da Silva', Maria Clara Barroso Mantel', Maria Cristina Mitsuko Peres', Tatiane Nunes da Silva Santos Luna', Priscila

Neves da Silva ${ }^{2}$

DOI: 10.1590/0103-11042020E226|

\begin{abstract}
The purpose of this article was to deepen discussions on the disaster that occurred in Brumadinho (MG), in January 2019. From the report of the seminar 'Disaster of Vale S.A. in Brumadinho: six months of impact and actions', six students from the Specialization Course in Public Health at Oswaldo Cruz Foundation (Fiocruz) and a postdoctoral fellow at Fiocruz in Minas Gerais performed transcriptions of speeches made during the event in an attempt to report this experience through different places of speech. Artistic experiences portrayed throughout the text establish a link with the subjectivity of those affected and their surroundings. Therefore, the article intended to follow that path.
\end{abstract}

KEYWORDS Disasters. Brumadinho. Mining. Unified Health System.

RESUMO O presente artigo teve como objetivo aprofundar discussões do desastre ocorrido em Brumadinho (MG), em janeiro de 2019. A partir da relatoria do seminário 'Desastre da Vale S.A. em Brumadinho: seis meses de impacto e ações', seis alunas do Curso de Especialização em Saúde Pública da Fundação Oswaldo Cruz (Fiocruz) e uma pós-doutoranda da Fiocruz de Minas Gerais realizaram transcrições de falas feitas durante o evento na tentativa de reportar essa vivência mediante lugares de fala distintos. Experiências artísticas retratadas ao longo do texto estabelecem um vínculo com a subjetividade dos atingidos e seu entorno. Portanto, o artigo pretendeu seguir esse caminho.

PALAVRAS-CHAVE Desastre. Brumadinho. Mineração. Sistema Único de Saúde.

\footnotetext{
1 Fundação Oswaldo Cruz (Fiocruz), Escola Nacional de Saúde Pública Sergio Arouca (Ensp) - Rio de Janeiro (RJ), Brasil. giuliabalbicosta@gmail.com 


\section{Introduction}

On January 25, 2019, the B1 dam, of the Córrego do Feijão mine, property of Vale SA, was broken. The breach immediately killed 272 people, including 22 still missing, in addition to exposing environment and population to the toxicities present in mining tailings.

The mud spread over nine census sectors in the municipality, which represents more than $10 \%$ of the population from Brumadino, including traditional communities and farmers. Still, it impacted biodiversity, changing the cycle of vectors and hosts'; disabled the Paraopeba River for consumption, irrigation, fishing, bathing and leisure ${ }^{2}$; significantly compromised the economic and financial organization of the municipality, among innumerable impacts that overlaps and affects the health of the entire population.

This is considered the biggest work accident in the history of the Country, considering that, at the fateful hour of 12:28, pm the workers were in the cafeteria when they were caught by surprise. The fact that the company's cafeteria and administrative building were located on the mud avalanche route is an indication of a failure in the company's work safety and monitoring policy.

However, technical failures point to structural issues, such as the adoption of an extractive development model, dependent on the mineral sector and a weakened state, facilitating corporate interests, which eases environmental and regulatory laws and allows practices such as self-monitoring of companies ${ }^{3}$.

More than six months after the event, the waste mud dried and became dust, and mixed with the mist that gives the city its name. The population continues in chronic suffering, aggravated by the feeling of injustice and without a number of uncertainties. The public health sector, even though has offered a quick and efficient response, in the medium and long term, will have to deal with demands that goes beyond its normal operating and financing conditions.
In this context, the seminar 'Disaster of Vale SA in Brumadinho: six months of impacts and actions', promoted by the Oswaldo Cruz Foundation (Fiocruz) on the 15th and 16th of August 2019, brought together representatives of public sector institutions in its three levels: teaching and research, artists and affected community, with the objective of offering a space for exchanging experiences and information, pointing the need to promote public policies that defend civil rights and the environment.

\section{Methodology}

This production is an experience report from a group of students of the specialization course in Public Health (Sergio Arouca National School of Public Health (Ensp/Fiocruz) and postdoctoral fellow in Public Health (Instituto René Rachou - Fiocruz Minas), who participated as rapporteurs for the seminar 'Disaster of Vale SA in Brumadinho: six months of impacts and actions'. During the event, the students worked on the synthesis of the discussions presented at the seven tables that composed it, seeking to condense the multiplicity of themes that emerged.

The round tables were: Impacts and actions of the SUS after the most immediate period to the disaster; Mining dam disasters - current and future risks; Being hit by mining dams current situation and future prospects; The social and economic consequences of mining dam disasters in the affected municipalities; Development model, mining dam disasters and health impacts; Disaster risks in mining dams and warning and alarm systems - current situation and future proposals; Mining dams and rights violations.

Given the scope of the debates presented and the impossibility of contemplating everyone for the production of this publication, there was a choice for the strategy of, based on the content analysis, electing three central axes as an itinerary for writing. Once the path of this production was established, the contributions of 
researchers and affected people, present at the themes mentioned above, who dialogued with the axes distributed in the sections were selected.

In the first section, some of the issues that produce the structural risk of disasters are discussed, in tension with the debate on human rights. In the second section, some of the actions of the public health system are presented, which needed to be managed in order to respond to emerging demands, as well as studies that deal with the toxicity of the Paraopeba River water. In the last section, an argument is made about the importance of seeing and hearing the affected community, including the poetry of a local artist.

The sections are marked by photographs by one of the authors of this text, who may be absent from the task of reporting on the event, placed in the town hall of Brumadinho, for a visit to the rural area of the municipality. The presentation of these records throughout the text was considered important because it is understood that the images also communicates and represents, in this case, an important aspect of the experience lived by the students, who accessed the field for the first time.

The contact with the field, the meeting with the characters who were present at the seminar and the work of rapporteur of the discussions mobilized the students who, contaminated by the atmosphere, used as a resource to present the results a composition of excerpts from the speeches of some of the present debaters at the meeting. The option for this resource is related to the intention of multiplying the voices that were present at the seminar heard; aiming to bring to the community the experiences lived during the event.

These speeches were transcribed from videos made by the production of the event, publicly available on the YouTube website. It is possible to find it through the title of the seminar 'Disaster of Vale S.A. in Brumadinho: six months of impact and actions; 2019'.

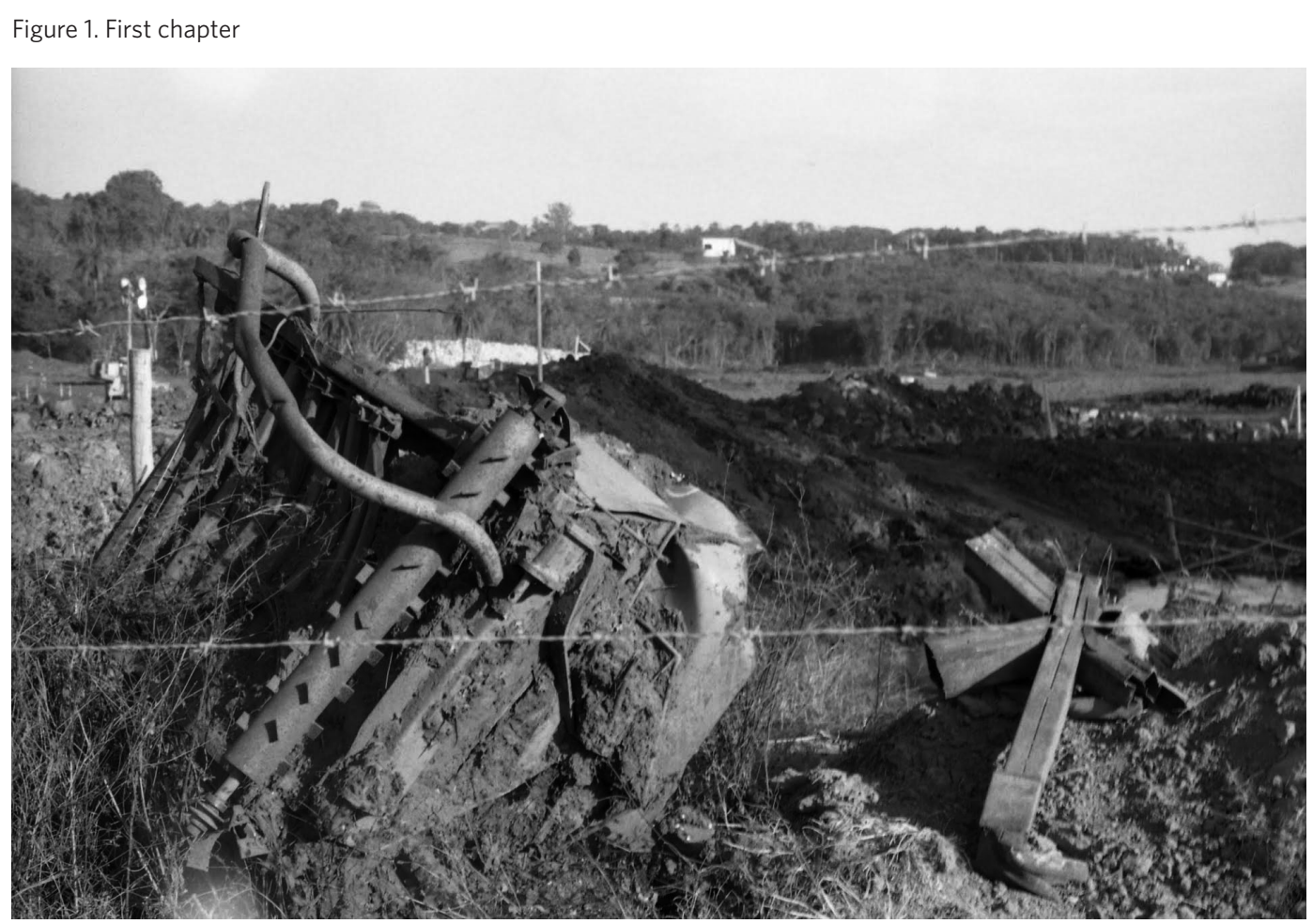

Source: Collection of Giulia Balbi, also author of the text. 


\section{Structural risks}

The capitalist development model, adopted after the industrial revolution, combined with the globalization process that places peripheral countries in a situation of economic dependence on economically and politically strengthened countries, favors their subordination to multinational companies. Such fragility prevents peripheral countries from being able to position themselves and face this exploratory process, making the environmental and labor laws that regulate the performance of companies more flexible and facilitating private interest. Thus, the search for progress and development, combined with the search for economic growth, has led many countries to admit the predatory exploitation of their natural and human resources 4 .

Regarding the weakening of State power, geographer Milton Santos points out:

As the institute in charge of taking care of the general is weakened, we are installing fragmentation in the territory; we are installing an abandonment of the notion of solidarity; we are, at least in the medium term, producing the preconditions of the disorder ${ }^{5(6)}$.

This form of exploitation also deterritorializes part of the population when it does not place them in a situation of socio-environmental vulnerability, increasing the risk to health due to contact with chemical, physical and biological contaminants. It should be noted that the risk generated is not equally distributed; and vulnerable populations suffer the most from the consequences of this development model. Thus, issues such as democracy, social and environmental justice, quality of life and human rights are subjugated, deepening social inequalities, environmental degradation and configuring a scenario of structural disaster risk, as pointed out during the Seminar by anthropologist Andréa Zhouri (Group of Studies in Environmental Issues - Gesta/Federal University of Minas Gerais - UFMG), shown in the excerpt below:
In the perspective of Political Ecology that guides our investigation, disasters are not natural phenomena, they are socially constructed processes... Disaster is a process! I would like to repeat here in a loud tone: disaster is not the rupture of the dam, people confuse disaster with rupture and even call it an 'event', that is a critical event within a disaster process, which begins before that and goes on ${ }^{6}$.

The appropriation process of the territory by development, followed by deterritorialization, also subtracts from traditional and local populations, the ability to use their knowledge and practices as tools for the search for survival, thus leading them to seek other forms of life that distance from their original cultures. In Brumadinho, "it is estimated that there are 147 and 424 communities (indigenous, quilombolas, foresters and artisanal fishermen) affected"1(2), in addition to family farmers. In this situation, there is a feeling of loss of identity and belonging that permeates these populations, as one affected person, resident of Brumadinho, expressed during the Seminar:

I was asked [sic], what is your proposal for Vale, farmers? A farmer does not know how to do anything else, besides taking care of the land [...]. I have a son who now had to work in another way, learn another profession, I have a son who was a farmer and now he have to learn how to deal with ore, right? Because that's what we have now?

The statement above conveys the perversity related to the conjuncture, a situation in which other forms of subsistence end up suffocated by the region's economic dependence on the mineral sector, even in the postdisaster moment, since the contamination of the Paraopeba River

made its use unfeasible for human or animal consumption, for irrigation, fishing, bathing, among other direct or indirect damages to those who benefited from the use of water ${ }^{\mathbf{2 ( 1 )}}$. 
A contradiction present in the territory is the fact that the health system of the municipality was able to offer a quick response in the post-disaster, in part, due to the compensatory taxes paid by the mining activity, which favored the organization of the local health system and at the same time, exposing the population to the risk of disaster.

Researcher Luiz Jardim (Poemas/University of the State of Rio de Janeiro - Uerj), present at the Seminar, debates the political relationship of mining with the public authorities, showing a State subjugated by the economic dependence of the mineral sector, but also active as facilitator of corporate interests. It lists a number of mechanisms of this public-private porosity, such as campaign financing and lobbying at the federal level, the effective participation of its representatives in environmental councils, the 'revolving door' feature, among others. About the possible economic benefits of mining to the municipality, he warns:

[...] Then we think: Well, mining brings jobs, income, and the municipality gets wonderful. Not quite, the salary range is around 1 to 5 minimum wages in the extractive sector in Brumadinho..., But, Brumadinho has an alarming fact, $33 \%$ of households live with per capita income below half a minimum wage! Mining is not bringing all this revenue to the municipality, as it is operating 8 .

It can be said, therefore, that the current development model, combined with globalization, stimulates the exploitation of economically, politically and socially more fragile countries by multinational companies, favoring the violation of human rights by companies and the State itself by not promote, protect and guarantee these rights.

In addition, it is important to remember that in 2015, Member States of the United Nations signed a Global Agreement agreeing on objectives to be achieved by 2030 that aimed to eradicate poverty, protect the Planet and ensure that individuals achieve peace and prosperity. However, these objectives will only be achieved if the current development model is rethought.

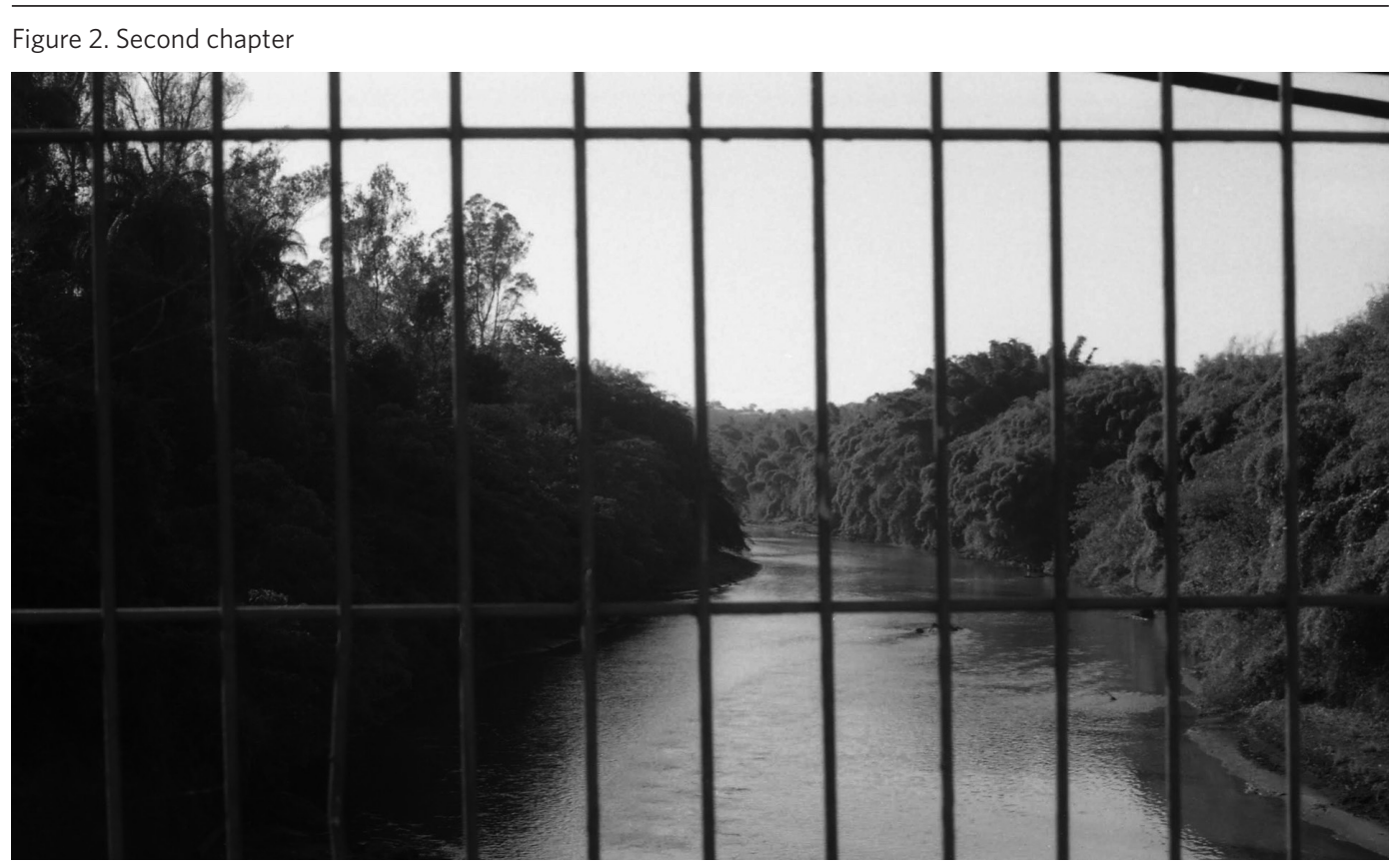

Source: Collection of Giulia Balbi, also author of the text. 


\section{Impacts on health}

In view of the Brazilian historical context, it is possible to observe how the political and economic organization produces socioenvironmental inequalities and influences the structural risk of disasters in mining dams. In the last five years, in the state of Minas Gerais, two major disruptions occurred in different locations, causing profound impacts and altering not only the living conditions of the affected population, but also the economic and financial organization of the municipalities.

Therefore, it is important, after events of this magnitude, to determine the risk management processes before, during and after a disaster, by establishing the dangers to which the population is exposed and which health conditions may affect the population, with the intention of alleviating them.

During the Seminar, efforts were made by public health services to offer a quick and efficient response to the community, establishing an Emergency Operations Center in health councils at the municipal, state and federal levels, with the purpose of defining daily strategies to be performed. In addition, the municipality obtained support from the National Force of the Unified Health System (SUS), Doctors Without Borders, Red Cross, Fiocruz, among many volunteers and institutions.

However, this was only possible because, at the time of the disaster, the territory had a structured and organized public health system, fully covered by the Family Health Strategy (FHS), formed by 14 units and 2 teams from the Family Health Support Centers (Nasf). In the medium complexity, the municipality had: Polyclinic; Physiotherapy's clinic; Child Psychosocial Care Center (Capsi); Psychosocial Care Center (Caps); Psychosocial Care Center for Alcohol and Other Drugs (Caps AD); Center for Integrative and Complementary Practices (Nupic); Emergency Care Unit (UPA) open 24 hours a day and a small hospital ${ }^{2}$.
In the post-disaster period, the municipality's health system was managed according to emerging demands, undergoing changes especially with regard to mental and psychosocial health care, in a context in which the use of anxiolytics and antidepressants increased by $60 \%$ and $80 \%$ respectively. In this way, the Psychosocial Care Center (Caps) device went from level 1 to level 2, in addition to Child Psychosocial Care Center's (Capsi) accreditation of the territory's care network, in order to meet previously existing as well as emerging demands.

In addition, three mental health matrix teams were formed with the objective of being itinerant, which is, to be present throughout the territory, welcoming subjects and collecting important data for the reorganization of this system. Primary care teams have also carried out work within the community, with the intention of identifying the population's signs of illness and offering the possibility of monitoring in the territory, relieving the subject of the obligation to attend a health device.

On the lines of care, José Geraldo, representative of the Movement of People Affected by Dams (MAB), signals a possible bet:

[...] we want integrative practices, popular care and other forms of care that will free us from the disease industry. Otherwise, in addition to breaking the dam and causing a crime, it will still make a profit for the pharmaceutical industry 9 .

After the tailings dam breaking, the affected population ended up exposed to residues originating from the mining production process, from direct contact with the mud to the consumption and use of contaminated water. In addition, after the mud dried up, it became dust and spread throughout the city, which creates deep uncertainty about its possible health impacts and concerns the affected community.

Consequently, the analysis of the toxicity of chemical, physical and biological agents 
resulting from this process is essential both for the dimension of illness and diseases that may manifest in the territory and for guiding the longitudinal actions of Unified Health System (SUS) and to guarantee the population the right to accurate and adequate information.

The disease process due to chemical compounds exposure has multivariate expression and several determinants. According to the 'Environmental Epidemiology Manual':

Individual susceptibility can be understood as innate or acquired characteristics that make an individual more or less sensitive to the effects of exposure to an intoxicant. Genetic characteristics can make individuals more or less tolerant to the effects of exposure to a toxicant ${ }^{10(41)}$.

Researcher Mônica Lopes Ferreira (Butantan Institute), present at the Seminar, presented a research carried out in partnership with the Federal University of Rio de Janeiro (UFRJ), in which the toxicity of the water of the Paraopeba River was analyzed in seven samples collected between the months of February and July 2019. The analysis detected the presence of large amounts of iron, aluminum and mercury; added to this is the aggravation that the concentration of this last element was 720 times above that allowed for class $2^{4}$ waters. When metagenomic analysis was performed, the presence of bacteria such as salmonella and cyanobacteria was detected, which cause damage to human health.

A study was carried out using the Zebrafish model in which such fish were exposed to samples of the river water. The study revealed the following results: delayed embryonic development, scoliosis, absence of mouth, pericardial edema, hemorrhage and mortality.
It is noteworthy that these fish have $70 \%$ of genetic similarity with the human species and that, even after diluting the sample in $650 \mathrm{x}$, such anomalies manifested, alerting to negative outcomes of the population's exposure to mud and contaminated water from the Paraopeba River .

After the researcher's presentation, a representative from the Pataxó village spoke up; his speech was followed by applause from the audience:

[...] [sic] When I say in my lectures that the river is dead, people laugh at my face, but I loved this because I don't have a laboratory like you but I had the opportunity to do the research in a box water without products and the fish were born all deformed and died after two days and I was moved by your speech this afternoon ${ }^{11}$.

Researcher Carmem Froes (Institute of Collective Health Studies - Iesc/UFRJ) debates about the sense of expanded health, in which the causal nexus is not enough to objectify the impact on health, since a multiplicity of economic, psychosocial and exposure factors may pose additional risks to the post-disaster reality:

[...] Any and every illness processes, this is the basis that we work on, it is a consequence not only of exposure to a physical agent, a chemical agent or a biological agent. It has always been, it will always be from the set of economic, social, cultural, genetic, environmental conditions of a municipality, of a locality, of the place where you live. And this will directly interfere in the perception and health condition of individuals and in the analysis of the health conditions of a population ${ }^{12}$. 
Figure 3. Third chapter

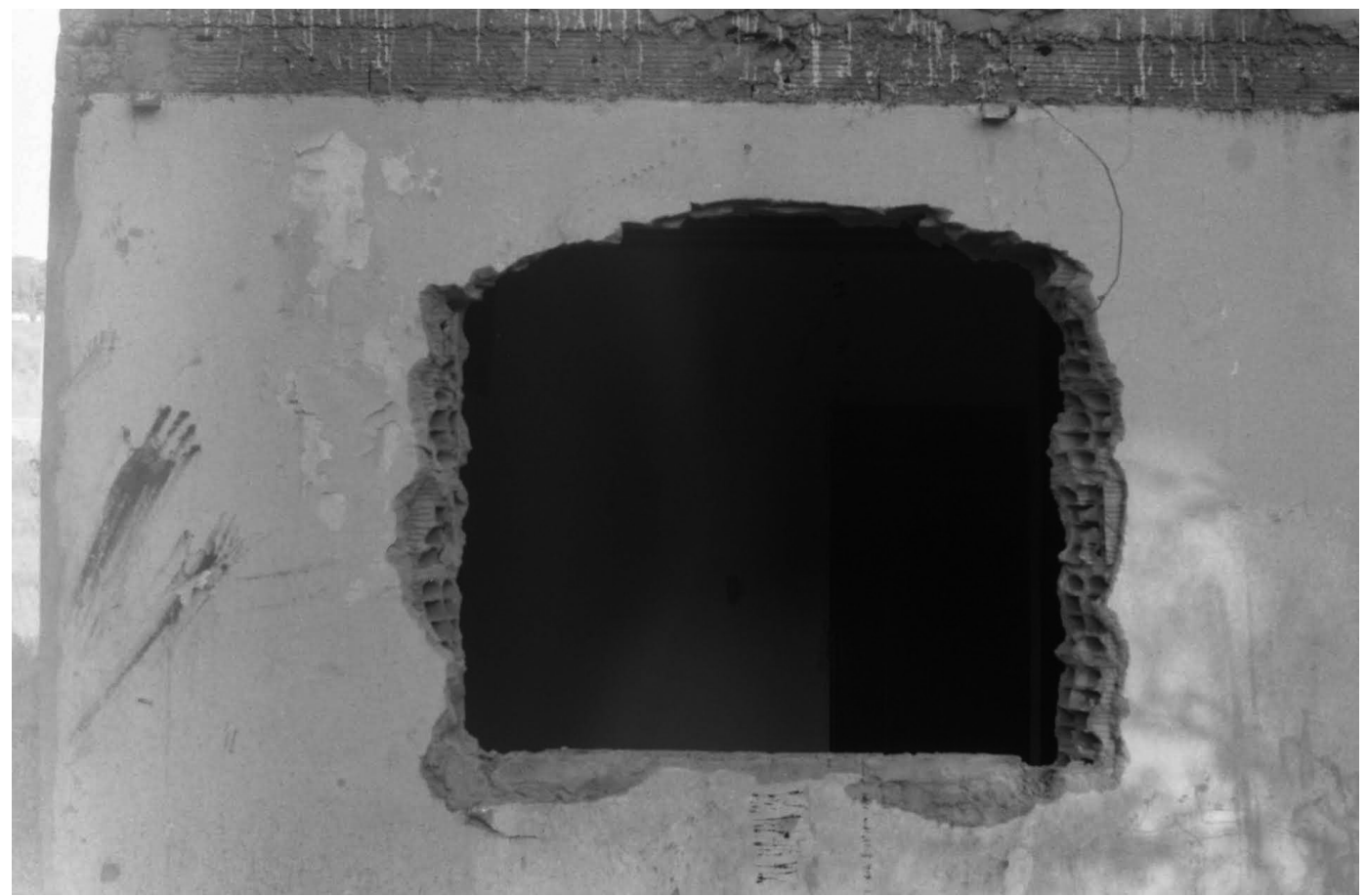

Source: Collection of Giulia Balbi, also author of the text.

\section{To see and hear}

After the development of several essential topics for the discussion presented in this article, a reflection will be made on the importance of listening to the voice of the individuals affected by the dam breaking.

The word 'hit' is used as a way of referring to speeches made by people who have had the experience of having their territories and their lives modified by the rupture of the dams. Understanding that this event brings different versions and different analysis, there is an impasse in relation to the terms used to refer to the people who live the situation. According to the 'Civil Defense and Protection Glossary', which has been a reference to understand the risks of disaster in Brazil, the term used to define these subjects is 'affected'. For them, "affected is any person who has been hit or harmed by a disaster (displaced, homeless, injured, etc.)"13(9).

On the other hand, in the scientific community, the expression is broadly defined:

In addition to the numbers of 'affected' traditionally defined by the Civil Defense (homeless, displaced, dead, injured and sick) and recorded during the rescue and relief period, one must consider all those who have had their living and working conditions affected in the different territories ${ }^{1(2)}$.

In addition to having their home invaded by mud or the loss of a family member, there are effects that expand in space-time continuum and irreparable damage caused by social and ecological change in that environment.

However, it is clear that there are different views from different characters within 
this context. Being considered a hit subject or an affected subject makes a difference to those who have suffered from the disaster. Thus, giving visibility to the speech of these individuals is fundamental to the report proposed in this text.

When it comes to bringing the speech of these subjects, it is necessary to look at the concept of place of speech, much discussed by the philosopher Djamila Ribeiro. In order to clarify a central issue within social movements, the thinker brings her contributions about this. According to her theory,

'Place of speech' can be understood as the point from which each person understands the world and, therefore, constructs interpretations about it, conducts research and produces knowledge. More than that, it highlights that our way of understanding the world is permeated by structural elements such as class, race and gender ${ }^{\mathbf{1 4}(210)}$.

Following this reasoning, therefore, and transporting it to our discussion, it is extremely important to regard the affected people as having knowledge and the needs that exist in their lives, and should be considered, that is, seen and heard; active individuals in the risk management and territory reconstruction process.

Thus, the territory is understood as a concept that goes beyond the physical space, becoming a subjective space constituted by social processes. Based on Milton Santos' idea of living territory, "the territory would encompass the physical characteristics of a given area, as well as the marks produced by man"15(596). In other words, the territory is defined as a dynamic whole in which economic, social and political interactions occur. Furthermore, in this sense, it is understood as a space in which there is an exchange of material and immaterial affections.

It is possible to think about the importance of building science and knowledge engaged and committed to the territory, culture and community. During the opening of the Seminar, Zélia Profeta da Luz (René Rachou Institute - Fiocruz Minas) points out the powers of building a debate that relies on contributions in opening up to dialogue with art:

[...] And then the reason for putting art is because of the understanding that art helps us a lot in those moments, right? Art have a transformation role... So we decided to have this discussion today and tomorrow with the experts, but also bringing a lot of art to help us build all of that ${ }^{16}$.

With that said, it was decided to exhibit here, as an inspiration, a poem transcribed from a declamation recorded on video during the Seminar of Sérgio Papagaio ${ }^{17}$, a poet and person affected by the Samarco disaster in Mariana.

Minas will be flat

There will be no more

The charm of the mountains

Its murky waters

Its roads without curves

Its mysteries unraveled

Its sleeps overflowed

Its people upset

Chased away

Scared

Leveled the horizon line

For the devil will eat your mounds

Minas will turn into a big bullion

Of solid iron

A mixed gold bar

At the sound of the people

Chanting a cry for help

Under the domination of Vale

With its trident

Minas now ill

Will send to the sea

The rest that's left

of the verb to mine [free translation] 


\section{Conclusions}

The disasters in mining dams, resulting from technical failures and historical and structural processes, constitute an enormous challenge to collective health, since they expose the population and the environment to overlapping multifaceted risks. The contact with toxic agents present in mining tailings even disruptive feelings of loss of identity and community memory, financial disorganization of the municipality, among many others. In this way, they produce diseases that manifest themselves immediately, but also in a longitudinal way, over time, surpassing the functioning conditions of the municipality's health system.

Six months after the Vale SA disaster in Brumadinho, and four years after the Samarco disaster in Mariana, there is a clear need for reflection on the development model adopted in the Country, which weakens the power of the State and generates socio-environmental inequalities and risks to human rights.

In spite of this, the seminar 'Disaster of Vale SA in Brumadinho: six months of impacts and actions' points to another possible path, based on the active listening of the actors involved in the process, the participation of those affected, the use of art - this one showing the suffering arising from the disaster process

\section{References}

1. Freitas CM, Barcellos C, Asmus CIRF, et al. Da Samarco em Mariana à Vale em Brumadinho: desastres em barragens de mineração e Saúde Coletiva. Cad. Saúde Pública [internet]. 2019 [acesso em 2019 jun 30]; 35(5):1-7. Disponível em: https://www.scielosp. org/article/csp/2019.v35n5/e00052519/.
- in dialogue with an engaged and supportive science. Furthermore, this meeting facilitates the articulation of the public sector, favoring the conditions so that it covers the company's responsibilities.

\section{Collaborators}

Costa GBR (0000-0003-0523-4511)* contributed to the planning, elaboration of the draft, critical review of the content and approval of the final version of the manuscript. Lau GR (0000-0003-4116-6755)* made a substantial contribution to the design and planning; elaboration of the draft; and participation in the approval of the final version of the manuscript. Silva CF (0000-0002-5072-2744)* contributed to the design; data analysis and drafting of the manuscript. Mantel MCB (0000-0001-7838759X)* contributed to the design; planning and drafting the manuscript. Peres MCM (0000-0002-5317-8465)* contributed to the concept; interpretation of data and drafting of the manuscript. Luna TNSS (0000-00029697-5640)* contributed to the conception, planning and drafting of the manuscript. Silva PN (0000-0001-8909-4477)* contribution to the planning, data analysis and drafting of the manuscript.
*Orcid (Open Researcher and Contributor ID)
2. Silva Noal D, Rabelo IVM, Chachamovich E. O impacto na saúde mental dos afetados após o rompimento da barragem da Vale. Cad. Saúde Pública [internet]. 2019 [acesso em 2019 jun 30]; 35(5):1-3. Disponível em: http://www.scielo.br/scielo.php?script=sci arttext\&pid= S0102-311X2019000600503. 
3. Milanez B, Magno L, Pinto RG. Da política fraca à política privada: o papel do setor mineral nas mudanças da política ambiental em Minas Gerais, Brasil. Cad. Saúde Pública [Internet]. 2019 [acesso em 2020 jan 22]; 35(5):e00051219. Disponível em: http://dx.doi. org/10.1590/0102-311x00051219.

4. Grisul U. PACHA: Defendendo a Terra: Extrativismo, conflitos e alternativas na América Latina e no Caribe [internet]. 2018. [acesso em 2019 jun 25]. Disponível em: http://www.grisulunirio.com/wp-content/ uploads/2018/11/Cartilha_Final_Internet-Port.pdf.

5. Santos M. Da Política dos Estados À Política Das Empresas. Cad. Esc. Legisl. 1997; 3(6):1-9.

6. Zhouri A. Seminário Desastres da Vale S.A. em Brumadinho: seis meses de impacto e ações 2019, parte 4. [vídeo] [internet]. [acesso em 2019 set 3]. Disponível em: https://www.youtube.com/watch?v=sl5Cq7egrhM.

7. Campos S. Seminário Desastres da Vale S.A. em Brumadinho: seis meses de impacto e ações; 2019, parte 2. [vídeo] [internet]. [acesso em 2019 set 3]. Disponível em: https://www. youtube.com/watch?v=3TQVHvZQCSs.

8. Jardim L. Seminário Desastres da Vale S.A. em Brumadinho: seis meses de impacto e ações; 2019, parte 2. [vídeo] [internet]. [acesso em 2019 set 3]. Disponível em: https://www.youtube.com/ watch? $=\mathrm{cXBwOyH} 58 \mathrm{Qc} \& \mathrm{t}=8616 \mathrm{~s}$.

9. Geraldo J. Seminário Desastres da Vale S.A. em Brumadinho: seis meses de impacto e ações; 2019, parte 4. [vídeo] [internet]. [acesso em 2019 set 3]. Disponível em: https://www.youtube.com/watch?v=sl5Cq7egrhM.

10. Braga ALF, Pereira LAA, Martins LC, et al. Manual de Epidemiologia Ambiental [internet]. Santos: Puc-Santos; 2015. [acesso em 2019 set 3]. Disponível em: https://www.unisantos.br/wp-content/uploa-
ds/2018/05/Vigilancia-saude-ambiental-superior.

pdf.

11. Peixoto C. Seminário Desastres da Vale S.A. em Brumadinho: seis meses de impacto e ações; 2019, parte 2. [vídeo] [internet]. [acesso em 2019 set 3]. Disponível em: https://www.youtube.com/ watch?v=3TQVHvZQCSs\&t=9551s.

12. Froes C. Seminário Desastres da Vale S.A. em Brumadinho: seis meses de impacto e ações; 2019, parte 2. [vídeo] [internet]. [acesso em 2019 set 3]. Disponível em: https://www.youtube.com/ watch?v=3TQVHvZQCSs\&t=9551s.

13. Secretaria Nacional de Proteção e Defesa Civil. Manual de Proteção e Defesa Civil. Brasília, DF: Sedec; 2017.

14. Kyrillos GM. "O que é Lugar de Fala?" De Djamila Ribeiro. Cap. Críptica. 2018; 7(1):209-214.

15. Araújo Lima EMF, Yasui S. Territórios e sentidos: espaço, cultura, subjetividade e cuidado na atenção psicossocial. Saúde debate. 2014; 38(102):593-605.

16. Luz ZP. Seminário Desastres da Vale S.A. em Brumadinho: seis meses de impacto e ações; 2019, parte 1. [vídeo] [internet]. [acesso em 2019 set 3]. Disponível em: https://www.youtube.com/watch?v=op_350lXdjs.

17. Papagaio C. Desastres da Vale S.A. em Brumadinho: seis meses de impacto e ações; 2019. [vídeo] [internet]. [acesso em 2019 set 3]. Disponível em: https:// www.youtube.com/watch?v=Z4fB9uLlwVo\&featur e=youtu.be.

\footnotetext{
Received on 09/30/2019

Approved on 03/10/2020

Conflict of interests: non-existent

Financial support: non-existent
} 